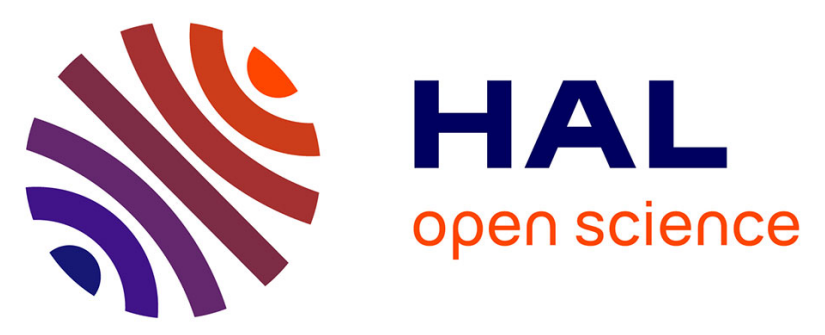

\title{
Risk Scenarios For Flash-Floods In The Rural Area Generated By Combined Hazard, Technologic And Natural
}

\author{
Ionel Haidu, Augustin Ionuţ Crăciun, Radu Alexandru Marian
}

\section{- To cite this version:}

Ionel Haidu, Augustin Ionuţ Crăciun, Radu Alexandru Marian. Risk Scenarios For Flash-Floods In The Rural Area Generated By Combined Hazard, Technologic And Natural. Carpathian Journal of Earth and Environmental Sciences, 2019, 14 (1), pp.181-190. 10.26471/cjees/2019/014/070 . hal02488129

\section{HAL Id: hal-02488129 \\ https://hal.univ-lorraine.fr/hal-02488129}

Submitted on 22 Feb 2020

HAL is a multi-disciplinary open access archive for the deposit and dissemination of scientific research documents, whether they are published or not. The documents may come from teaching and research institutions in France or abroad, or from public or private research centers.
L'archive ouverte pluridisciplinaire HAL, est destinée au dépôt et à la diffusion de documents scientifiques de niveau recherche, publiés ou non, émanant des établissements d'enseignement et de recherche français ou étrangers, des laboratoires publics ou privés. 


\title{
RISK SCENARIOS FOR FLASH-FLOODS IN THE RURAL AREA GENERATED BY COMBINED HAZARD, TECHNOLOGIC AND NATURAL
}

\author{
Ionel HAIDU ${ }^{1}$, Augustin Ionuţ CRĂCIUN ${ }^{2}$ \& Radu Alexandru MARIAN ${ }^{3}$ \\ ${ }^{1}$ University of Lorraine, Laboratory LOTERR - EA 7304, Ile du Saulcy, 57045 Metz, France, e-mail: ionel.haidu@univ- \\ lorraine.fr \\ ${ }^{2}$ Someş-Tisa Water Authority, Hydrological Station SGA Cluj, Donath Street 157A, 400293 Cluj-Napoca, \\ Romania, e-mail: hidro@sgacj.dast.rowater.ro \\ ${ }^{3}$ S.C. VITAL S.A., Gheorghe Sincai Street 21, 430011 Baia Mare, Romania, ralex_marian@yahoo.com
}

\begin{abstract}
Certain rural settlements situated in the floodplain area are exposed to a high risk of flash-floods, in case a sudden damage appeared in the supply water system network. The purpose of the present research is the anticipation of hydrological risk in this type of areas in case of a simultaneous occurrence of two types of hazard: torrential rain and damages to the supply water system network. Therefore we will use an ArcGIS procedure of building flash-floods scenarios generated by extreme events, namely the high level of soil saturation, damages to the supply water system network and a high intensity torrential rain. The article presents different scenarios according to the return period $(T)$ of the torrential rain: $T=20$ years, $\mathrm{T}=100$ years and $\mathrm{T}=1000$ years. The results will highlight the several vulnerability categories of the terrain and households related to combined risk. The flash-floods scenarios in the rural settlements that benefit from a supply water system network will be of great use to the local administrative authorities for the management of combined risk emergencies.
\end{abstract}

Keywords: flood, scenario, return period, rural, water supply network, hazard, susceptibility, vulnerability, hydrological risk.

\section{INTRODUCTION}

Natural or artificial floods that occur in rural areas are issues on which more and more research is being done. Flood modeling difficulties for rural settlements occur primarily due to the work at a large scale that requires the use of data sets which are often inaccessible without additional information. Many rural settlements are located in small basins that are generally not hydrometrically monitored. In addition, large scale work requires more spatially details for other physical-geographical parameters that are involved in this mechanism (leveling, slopes, soils, vegetation and others). The situation can become complicated if, besides the natural factors of local flooding, we add when dealing with a water supply network, the risk of damage to water pipe supply units. Our paper aims at contributing to solve this problem of runoff computation generated simultaneously by two factors: torrential rain plus discharge appeared due to the accidental damage of supply water system network.

The rural settlements in the confluence area of the Lăpuş River with its tributary Chechiş (Romania), represent the study area of this research (Fig. 1). This area has a water supply system, but since their location is the Lăpuş Valley, its areal is exposed to a high flash-flood risk in case damage to the supply system would appear, overlapping the moment of when a torrential rainfall occurred as well. The objective of the present paper is a hydrological risk assessment and identification of households situated in the flash-flood vulnerable areas. In order to fulfill the purpose of the present paper, an ArcGIS procedure has been elaborated in order to produce flooding scenarios generated by torrential rain with different return periods, superposed with the occurrence of a surplus in runoff due to the damage of the water supply network. 


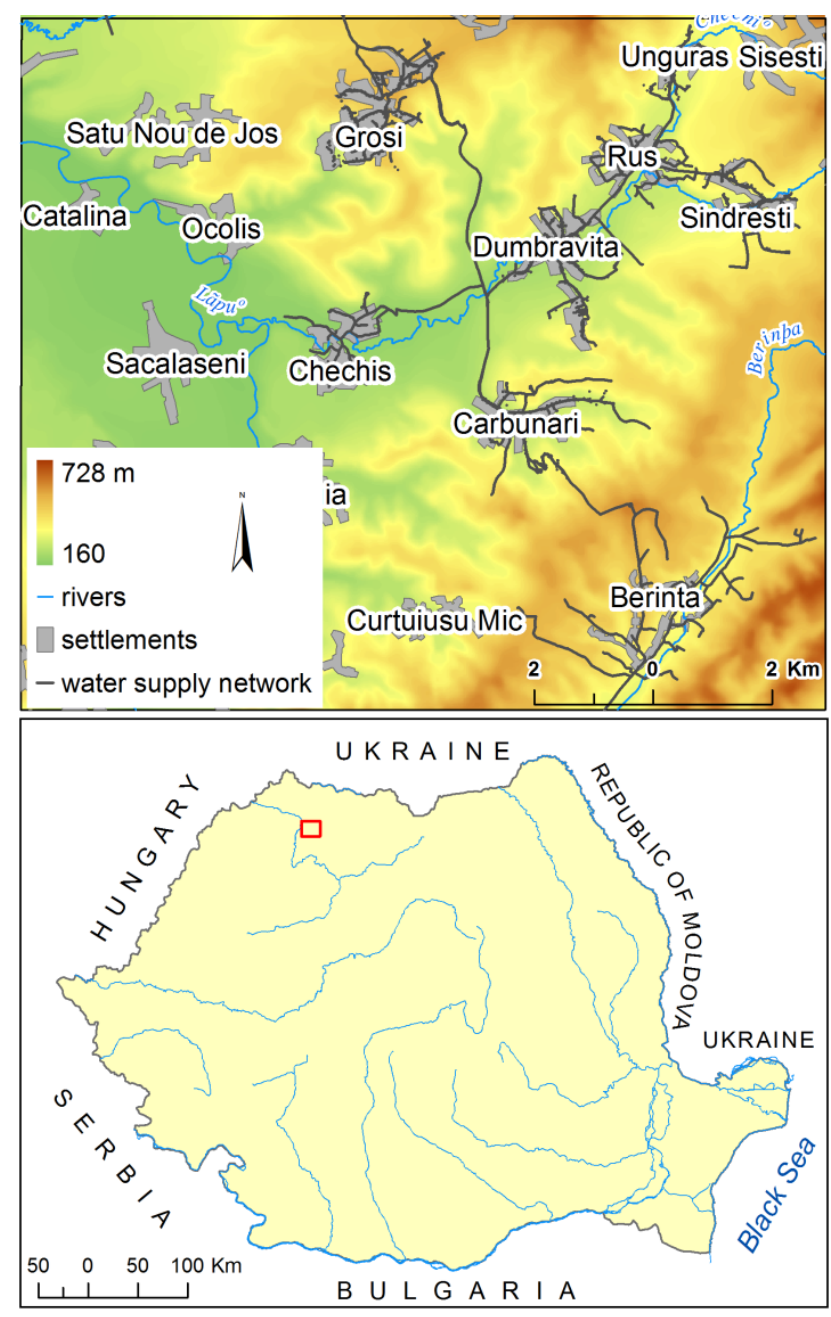

Figure 1. Location of the studied area on the Lăpuş valley.

Taher \& Labadie (1996) have been among the first to use GIS so as to develop a Water Distribution System Optimization Program knowing the pipes sections of a water supply network. Zoppou (2001) has compared several models of flow analysis with applications in urban environment and for non-urban areas, too. A model for the evaluation of flow in agricultural areas is presented by Wilkinson et al., (2008). Two handbooks for urban-storm water infiltration and urban flood risk reduction have been elaborated by Sandink (2009, 2011). Amaguchi et al., (2012), by making use of GIS possibilities as well, have dealt with the modeling and developing of an urban basin scale storm runoff event model. The spatial and temporal features of rainfall-runoff process in the small basins have been discussed by Sarpe \& Haidu (2017) and a review of methods of maximum discharge computation in ungauged river basins for Romania has been presented by Voda et al., (2018). As compared to the works afore mentioned, the present paper deals with the assessment of certain extreme flash-floods events generated by the combination of a torrential rain event of high intensity and the possible runoff occurred due to the accidentally damaged water supply network. Another new approach consists in the matter that we will present scenarios of the combined flash-floods, corresponding to the different return periods of the torrential rain.

Our study focuses on the villages Chechiş (175 $\mathrm{m}$ mean altitude) and Cărbunari (180 m mean altitude) both located generally along several small river courses with low altitudes and low slopes, favorable to moisturized land. The studied territory is a hilly unit, fragmented by valleys with $10-15$ degrees predominating slopes, nearing to 40 degrees only in a few cases. Regarding the soil, it has to be mentioned the predominance of clayey soil with a low infiltration capacity or clay texture with high infiltration capacity and higher retention. About vegetation, it should be mentioned that there is a high coverage with shrubs and deciduous forests, especially in the Northern and Eastern half of the area, with high water retention, which therefore can lead to quicker discharge coefficients. Some of the large areas are covered by agricultural lands that lead to higher values of discharge coefficients.

Many of the papers regarding the GIS in water supply networks focus on the design or the management of such networks or the setup of a geodatabase (Nicoară \& Haidu, 2011; Haidu \& Ivan (2016-a).

The high intensity torrential rains are indeed a possibility in this region (Zaharia et al., 2011; Tudose et al., 2013). The production of accidental damages of the water supply network and the apparition of an uncontrollable runoff are also possible and can have a wide number of causes (Keller et al., 2009-a; Keller et al., 2009-b). Therefore, Marian et al., (2012) have been elaborated a GIS procedure for the computation of the volume of surface runoff generated by failure pipe. The problem is not solved if one simply imagines pipes burst, it is actually necessary to calculate the amount of water needed to saturate the soil and then the manifestation of the drainage process. Unlike town's areas where land is generally impermeable (Ivan, 2015; Haidu \& Ivan, 2016-b), the situation is more complicated in the rural areas where it is necessary to take into account the hydrological conditions of the land, prior to the torrential rainfall.

In the present paper the hydrological risk is conceived as a result of the union of the three components: hazard (torrential rain with high return period registered simultaneously with damages of water supply network); susceptibility (the level of soil water saturation prior to rainfall, pipes with a high susceptibility to flooding in case of damage to the supply system) and the vulnerability (water 
volume registered as runoff due to the torrential rainfall and the damages produced; affected households, different landuse terrains affected).

\section{MATERIAL AND METHODS}

\subsection{Database}

The data used in the study is mostly derived on the basis of, cartographic materials. The numeric data is represented only by the daily precipitation data recorded at the meteorological station of Baia Mare during the 10th to the 24th September 2012. It would have been desirable to also have data from other monitoring sites, but since the study area is quite small, no other weather station exists, therefore the rain was considered uniform throughout the study area. In terms of cartographic data, the following were used: topographical plans for the villages Chechiş and Cărbunari in order to form a polyline vector GIS database for contour lines and hydrographical network; a digital elevation model (DEM) with spatial resolution of $10 \mathrm{~m}$ was generated with the method Topo to Raster; soil maps in order to extract soil type and texture and to build a polygon vector GIS database; the database was supplemented with attributes for name equivalence in soil types classification SRTS 2003 (Florea \& Munteanu, 2003) and hydrologic soil groups (HSG: A, B, C, D); the CORINE Land Cover (2000) database of land usage categories is used, too. This information was necessary for determining the role of the vegetation in the interception of the rainfall and the development of the surface runoff. However, to estimate the interception, a soil GIS database has been put together. For the water supply network a polyline type vector GIS database is created; the water mains pipe sections database of this rural area contains 406 sections. The nearest meteorological station is that of Baia Mare, situated at $6 \mathrm{~km}$ North of the two villages. The torrential rains registered here in the period of 1975-2012 have been used to develop the IntensityDuration-Frequency curves from which all of the specific return periods ( $\mathrm{T}$ ) have been extracted so as to build the flash-floods combined scenarios.

\subsection{Methodology}

Hydrological characterization of the land within the study was made by implementing in ArcGIS classic hydrological methods like: the API index (Antecedent Precipitation Index) and $C N$ index (Curve Number Index). The purpose of study algorithm is to identify the high-risk sections of the pipe which can generate local flooding in the event of damage (but depending on the moisture level of the land, as well) and to compute the runoff volume generated by technologic hazard (damages to the supply network system) and natural hazard (torrential rain).

Antecedent Precipitation index (API) was used to estimate basin moisture depending on rainfall characteristics of the analyzed territory (Heggen, 2001; Sample \& Heaney, 2006; Istanbullougu et al., 2006; Tramblay et al., 2012).

The main formula of this method was developed by Kohler \& Linsley (1949) and is presented below:

$$
I_{t}=K_{t} \cdot I_{t-1}+P_{t}
$$

$I_{t}$ - is API of day t (mm)

$K_{t}$ - is a subunitary parameter which depend to physical characteristics of basin

$I_{i-1}$ - is precipitation in antecedent day (mm)

$\mathrm{P}_{\mathrm{t}}$ - is precipitation of day $\mathrm{t}(\mathrm{mm})$

In our paper the ArcGIS functionality was used for modeling the API index and in order to split the hydrological elements like vegetation interception, soil water supply and drainage. It was used in the sense that the Frevert runoff coefficients determined by the slope, soil texture and land, are used for completing the equation of the drainage ability indicator (Crăciun, 2007; Crăciun et al., 2007, Crăciun et al., 2009).

Another hydrologic index implemented in the ArcGIS was the Curve Number (CN) index, a component of the SCS-CN method developed by the SCS-USDA (1986), completed by EWRI-ASCE (2009) and largely explained in the volume edited by Mishra et al., (2012). Mainly, it indicates the infiltration and runoff capacity for a territory using information on soil texture, soil hydrologic class, land use and antecedent moisture conditions (AMC). Subsequently on the basis of the Curve Number Index (CN) was computed the maximum retention potential (S), parameter that was used in determining the saturation coefficient of the terrain.

The stages undergone to obtain the maximum retention potential (S) with the help of GIS are the following: hydrological classification of soils, in hydrological soil groups: HSG (A, B, C, D) according to the soil infiltration capacity of the terrain and soil texture; extraction of the $\mathrm{CN}$ values for normal antecedent moisture conditions (CN II) according to the tables elaborated by SCS-USDA, but with CN adapted for the Romanian territory (Chendeș, 2007); adaptation of the $\mathrm{CN}$ values according to the antecedent moisture conditions (AMC I, II, III) according to the 5 previous days rainfall quantities.

The mathematical formulas used in this respect 
are (Luijten et al., 2002):

$$
\begin{aligned}
& C N_{I}=\frac{\left(-75 \cdot C N_{I I}\right)}{\left(-175+C N_{I I}\right)} \\
& C N_{I I I}=\frac{\left(175 \cdot C N_{I I}\right)}{\left(75+C N_{I I}\right)}
\end{aligned}
$$

and determining of the maximum retention potential on the basis of the formula

$$
S=\frac{25.400}{C N}-254
$$

The degree of soil saturation has been determined by dividing the soil water storage (computed via the API) and the maximum retention storage (S).

The use of GIS capabilities for watershed modeling is not a very new challenge. Several authors have used the GIS technology in order to automate the runoff calculation based on SCS method: Greene \& Cruise (1995), Sample et al., (2001), Gyori \& Haidu (2011), Gyori et al., (2016), Khaleghi \& Mahmoodi (2017). In the present case study the working procedure is based on the proposal of Mishra et al., (2004), regarding the incorporation of antecedent moisture into hydrologic modeling.

Our methodology is rather different from the ArcGIS tool of Zhan \& Huang (2004), because it includes more facilities for mapping soil hydrological characteristics at the cell level, like the work of Haidu et al., (2017), and for deriving flood risk associated to the water mains network. Except the computation of hydrologic indexes, no other formulas are necessary to be implemented in GIS. By the use of map algebra, overlay procedures, reclassification functions and queries, layers which served to generate the desired set of maps were obtained, emphasizing the pipe sections with high susceptibility to produce local flooding.

Regarding the runoff volume determination, the following stages have been undergone.

1. Computation of runoff available for natural drainage

2. Computation of water quantity generated by the natural runoff

3. Computation of the soil saturation subsequently to the torrential rain

4. Computation of runoff generated by the damage of the water supply pipes

5. Computation of the runoff generated by the damage of the pipe and the occurred rainfall.

There are other methods that can be employed so as to make an analysis of the hydrological soil conditions on a daily basis. For example, USDA-SCS has established a formula for the cumulative infiltration. There are as well a series of balance or physical methods that stimulate the infiltration process (Green and Ampt, Horton's formula, the Philip model).

An alternative is represented by the methods based on the use of certain technologies: (tensiometry, reflectometry, electro conductivity, neutronics). The development of technology allows nowadays having information at a high temporal and spatial resolution regarding the hydrological soil conditions or those of the Earth's surface with the help of Remote Sensing (Radar or Satellite Images). Hence this type of information regarding the hydrological conditions of the soil are taken during certain missions such as: SMOS (Soil Moisture and Ocean Salinity), ESTAR (Electronically Scanned Thinned Array Radiometer), ASAR (Advanced Synthetic Aperture Radar) on the ENVISAT satellite, LEWIS (L-band radiometer for Estimating Water in Soils) etc.

The procedure we have opted for, based on GIS so as to evaluate the hydrological conditions of the terrain on a daily basis, had been chosen as a consequence of the lack of measurements or observations needed to apply one of the very wellknown methods.

\section{HAZARD}

The hazard is the first component of the risk concept that must be studied, and refers to the origin of the hydrological risk phenomenon/event. We are considering two hazard categories: natural or the torrential rains and technologic or the damage to the water supply network.

In the case of torrential rains three scenarios were considered, with different return period ( $T$ ) for each rain ( $T=20$ years, $T=100$ years, $T=1000$ years). The quantitative features of torrential rains (intensity and duration) were obtained from the intensityduration-frequency curves from the Baia Mare weather station (based on data measured between 1975 and 2012). The table 1 presents the characteristics of the three precipitation scenarios on which the applications were based.

The water supply network has main pipes with diameters from 200 to $800 \mathrm{~mm}$, pipes with 100-150 $\mathrm{mm}$ diameter (in some cases even lower) and branch pipes. As regarding the technologic risk, Marian et al., (2012) have been noticed that thorough pipe damage could produce a discharge more than $60 \mathrm{~m}^{3} / \mathrm{h}$ in the network of Baia Mare region.

Since the paper is based on damage scenarios in different points of the water pipes (possible damage points) and not on already registered damage 
situations, we intended to localize the possible failure point of pipes that by breaking would produce serious damage. The highly susceptible pipes to determine floods in case of damage are indicated in the following section. When studying the vulnerability, some possible failure points on pipes with high damage susceptibility will be considered.

Table 1. Rainfall scenarios.

\begin{tabular}{|c|c|c|c|}
\hline Indicators & $\begin{array}{c}\text { Scenarios } \\
\mathbf{1}\end{array}$ & $\begin{array}{c}\text { Scenarios } \\
\mathbf{7}\end{array}$ & $\begin{array}{c}\text { Scenarios } \\
\mathbf{2}\end{array}$ \\
\hline $\begin{array}{c}\text { Return period } \\
\text { (years) }\end{array}$ & 1000 & 100 & 20 \\
\hline Probability (\%) & 0,1 & 1 & 5 \\
\hline $\begin{array}{c}\text { Rain duration } \\
\text { (min) }\end{array}$ & 30 & 30 & 30 \\
\hline $\begin{array}{c}\text { Rain intensity } \\
\text { (mm/min) }\end{array}$ & 0,6 & 0,47 & 0,29 \\
\hline $\begin{array}{c}\text { Rain quantum } \\
\text { (mm) }\end{array}$ & 18 & 14,1 & 8,7 \\
\hline
\end{tabular}

\section{SUSCEPTIBILITY}

The second component of the hydrological risk analyzed, the susceptibility, refers to the manifestation potential of the extreme hydrological phenomenon; it comprises the factors triggering the occurrence of the hydrological risk phenomenon. In our case these factors would be: soil saturation, the deterioration of pipes, and the high potential of failing pipes to determine floods in areas where water infiltration is limited (areas with high soil saturation). Lacking a quantified deterioration degree of pipes in the two analyzed villages, we considered just the evaluation of the soil saturation before the torrential rain and the identification of the pipes located in areas with high flood susceptibility in case of failure. The high flood susceptibility in case of failure was estimated according to the soil saturation.

The applications on soil saturation were performed starting from the calculation of soil water content (by using the API (Antecedent Precipitation Index method), and of the maximum available soil moisture (S parameter in SCS-CN method). The map of the soil water saturation coefficient shows an increase in the values in the forested areas situated on sunny slopes with large inclination towards urban built-up areas or areas located on shaded slopes and on lower slopes. High saturation coefficients can also be observed in the riverbeds of the main rivers that are draining the study area.

Extracting the areas having the coefficient of soil water saturation $\geq 0.5$, we have generated the raster map (Fig. 2) of areas likely to produce local flooding at a daily scale (one of the end result). Extracting the areas having the saturation coefficient successively $>0.5,>0.7$ and $>0.9$, we have defined three categories of susceptibility to local flooding: moderate, high and very high (Fig. 3). The figure presents the pipe sections with different degrees of susceptibility, in relation to the water saturation coefficient for the villages of Chechiş, and Cărbunari.

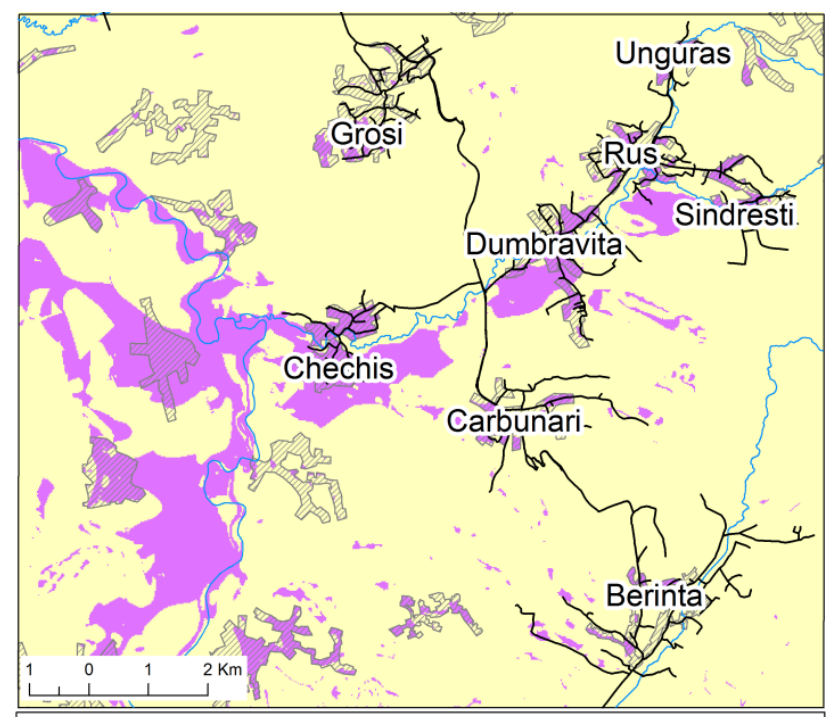

High susceptibility zones (soil saturation coefficient $\mathbf{>} \mathbf{0 . 5}$ )

$$
\square 0 \text { - } 0.5 \square 0.5 \text { - } 1
$$

river - water supply network $\square$ settlement

Figure 2. Susceptible areas to local flooding caused by potential damages to the water supply network.

Table 2. Cases of damages produced in 2012 within Chechiș and Cărbunari settlements.

\begin{tabular}{|l|l|l|l|}
\hline \multicolumn{2}{|c|}{ Chechiş } & \multicolumn{2}{c|}{ Cărbunari } \\
\hline Date & Adress & Date & Adress \\
\hline $07-02-2012$ & No.116 & $16-02-2012$ & No.205 \\
\hline $07-02-2012$ & No.17 & $02-04-2012$ & No.37 \\
\hline $29-03-2012$ & No.139 & $26-04-2012$ & No.144 \\
\hline $01-04-2012$ & No.79 & $10-05-2012$ & No.56/A \\
\hline $07-05-2012$ & No.211 & $22-05-2012$ & No.214 \\
\hline $03-06-2012$ & No.101 & $04-06-2012$ & No.156 \\
\hline $15-07-2012$ & No.196A & $05-06-2012$ & No.136 \\
\hline $11-08-2012$ & No.138 & $20-06-2012$ & No.104 \\
\hline $20-08-2012$ & No.196 & & \\
\hline
\end{tabular}

According to the results, a nearly saturated ground (soil saturation coefficient $>0.9$ ) would show a number of 21 sections of pipe to be with high susceptible to produce local flooding in Chechiş, and 11 sections in Cărbunari. 
The mean use span of water pipes is 8 to 10 years. The steel and asbestos cement pipes require high maintenance costs if used longer, because of cracks or frequent failure. The recorded maintenance interventions between 2001 and 2010 indicate a frequency of 4,4 damages $/ \mathrm{km} /$ year, and an average of 3 to 5 failures per day. Table 2 shows an overview of damages registered in Chechiș and Cărbunari in 2012.

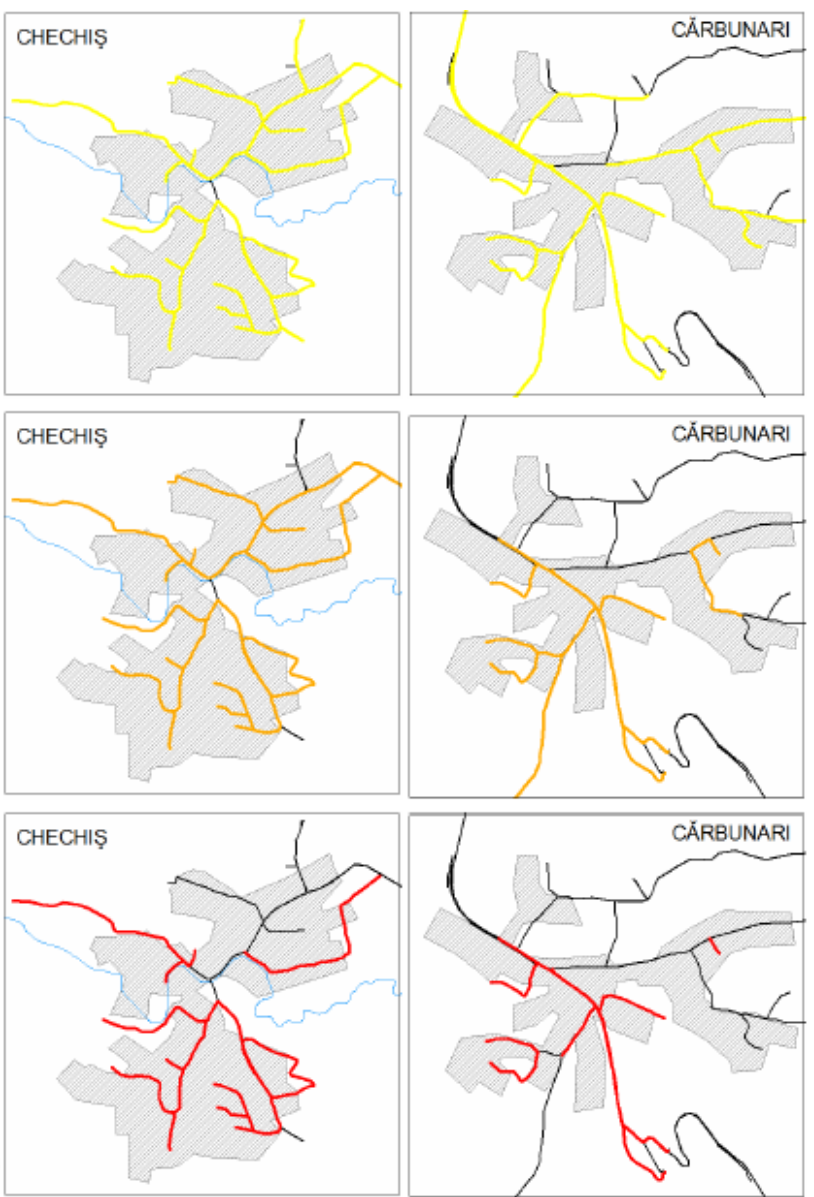

Pipe sections with moderate susceptibility (soil saturation coefficient $>0.5$ )

Pipe sections with high susceptibility

(soil saturation coefficient $>0.7$ )

Pipe sections with very high susceptibility

(soil saturation coefficient $>0.9$ )

Figure 3. Pipe sections with different degrees of susceptibility for local flooding, in relation to the water saturation coefficient for two villages: Chechis and Cărbunari.

They happened because of the pipes' age (over 31.5\% have they use span exceeded), the poor quality of the metal pipes, the poor quality of fitting or the poor anticorrosive protection against the high soil acidity resulted from the sulphurous dioxide emanated by the Chemical Plant in Baia Mare and the high concentration of oxygen (more than $14 \mathrm{mg} / \mathrm{dm}^{3}$ ) in the source water.

\section{VULNERABILTY}

Vulnerability, the third component of the risk concept, refers to the consequences resulting from the manifestation of the hydrological extreme phenomenon in the context of the fragility and the response capacity of the society (Albano et al., 2017; Haidu \& Ivan, 2016-c). In our case, the studied consequences derived from the occurrence of the two hazards (torrential rain and damage to the water supply network) are the water volume and the affectedness degree of the local community. Actually, we intend to answer to the following questions:

1. How much will the surface runoff mean?

2. Who will be affected by the surface runoff? According to the results presented in "Fig. 3" two possible damage points were identified for the pipes categorized as "pipe section with very high susceptibility". An "extreme" scenario was created choosing two possible damage points for the pipes located on the upstream slopes (Fig. 4).

For both possible damages a total failure of $5 \mathrm{~h}$ duration was considered. The average discharge of the water supply network being of $24 \mathrm{~m}^{3} / \mathrm{h}$, a total volume of $120 \mathrm{~m}^{3}$ is evacuated by the pipe during the failure. The evaluation of the runoff considered also successively the three precipitation scenarios detailed in table 1.

According to the applications performed, the relationships between the distance from the damage location covered by the runoff along the flow path and the different return periods were used to create new original graphs, figure 5 and figure 6 . They represent scenarios of mixed runoff (natural and technologic) because for successive return periods the water volume can be estimated along the torrential path.

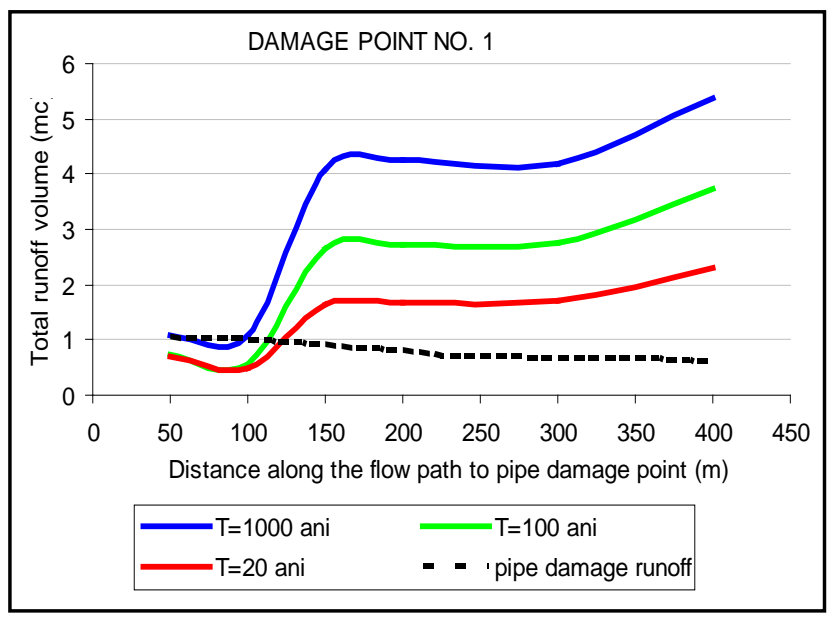

Figure 5. Total runoff volume according to the distance of the flow path for different return periods, damage 1 . 


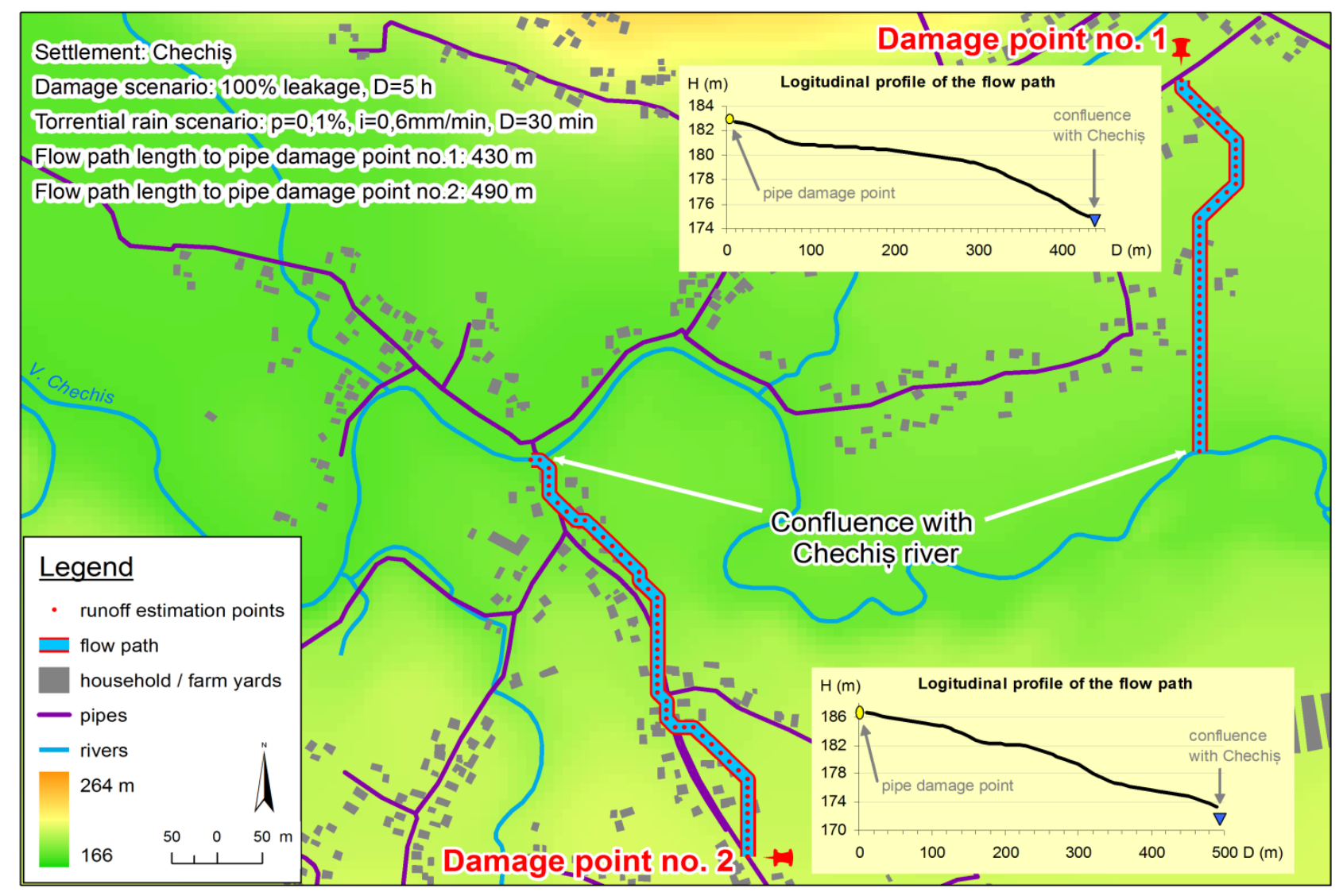

Figure 4. Damage points and the flow path in case of damages to the supply network system and a torrential rain $(\mathrm{T}=1000$ years $)$.

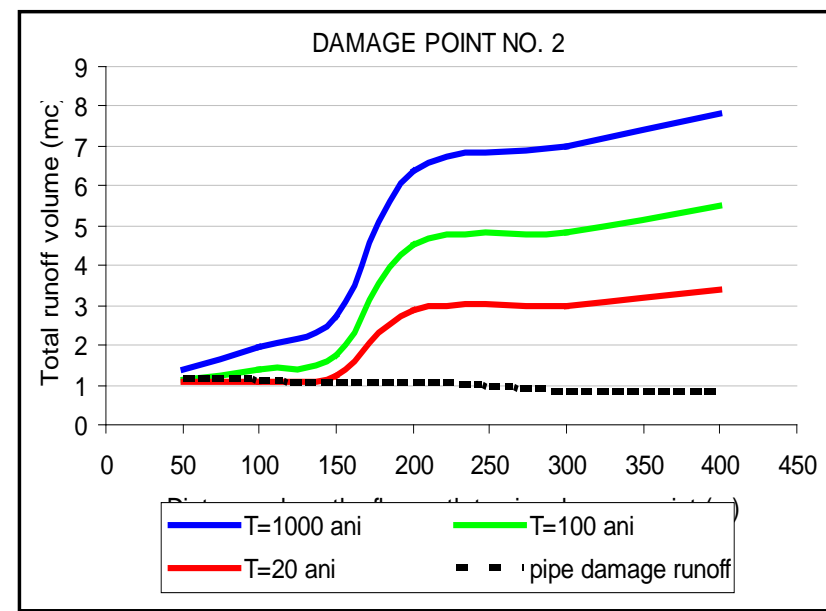

Figure 6. Total runoff volume according to the distance of the flow path for different return periods, damage 2 .

As a result of infiltration, a decrease in the volume of flowing water is emphasized for the first 50 $\mathrm{m}$ to $60 \mathrm{~m}$ downstream from the „technologic source” in the case of damage point no 1 scenario. After the distance of $60 \mathrm{~m}$, the runoff volume has a general increasing trend, especially due to the augmentation of water supply from the slopes. On this general increasing trend two sudden augmentations of the water volume appear: between $100 \mathrm{~m}$ and $150 \mathrm{~m}$ away from the damage point and downstream from the point situate $300 \mathrm{~m}$ away from the damage point. In addition to the water volume coming from the slopes, the explanation lies in the higher soil saturation that favors the flow in the two mentioned sectors.

A similar runoff evolution is observed for the damage point no. 2 scenario as well, the only difference being the occurrence of a sole sector with increase water volume; it appears at $150 \mathrm{~m}-200 \mathrm{~m}$ downstream from the damage point.

The vulnerability, expressed in the affectedness of the villages, is summarized in tabel 3, for the results of the scenario when a torrential rain with $\mathrm{T}=1000$ years return period overlaps a damage situation. For the 5 hour pipe failure alone, the flow path is of $187 \mathrm{~m}$ for the damage point no 1 scenario or $253 \mathrm{~m}$ for the damage point no. 2 scenario. When associated with a torrential rain of return period $\mathrm{T}=1000$ years, the runoff is along the whole flow path (430m and $490 \mathrm{~m}$ ) down to the Chechiş river. If the damage point no. 1 scenario is considered, only the pipe failure would affect by flooding or excessive moisture 2 households, 1 arable land and 1 grassland. If a torrential rain of $\mathrm{T}=$ 1000 years return period overlaps the pipe failure the number of affected elements increases (3 households, 3 arable lands and 2 grasslands). The morphological and hydrological characteristics of the area would 
Table 3. Comparative analysis of the hydrological impact generated by flooding. The case of only technologic damage to the water supply network versus the combinated events (technologic damage plus torrential rain with $\mathrm{p}=0.1 \%$ ).

\begin{tabular}{|c|c|c|c|c|c|c|}
\hline \multirow{2}{*}{$\begin{array}{l}\text { Damage } \\
\text { case }\end{array}$} & \multirow{2}{*}{ Scenarios } & \multirow{2}{*}{$\begin{array}{l}\text { Flow } \\
\text { Length (m) }\end{array}$} & \multicolumn{4}{|c|}{$\begin{array}{l}\text { Total runoff depth }\left(\mathrm{mm} / \mathrm{m}^{2}\right) \text { at } \\
\text { Distance of "x" from the damage point location }\end{array}$} \\
\hline & & & $50 m$ & $100 \mathrm{~m}$ & $200 \mathrm{~m}$ & $400 \mathrm{~m}$ \\
\hline \multirow{3}{*}{1} & Only damage & $187 \mathrm{~m}$ & 676 & 431 & 0 & 0 \\
\hline & $\begin{array}{l}\text { Damage + torrential } \\
\text { rain }\end{array}$ & $430 \mathrm{~m}$ & 1066 & 1074 & 4249 & 5369 \\
\hline & \multicolumn{2}{|c|}{ Landuse category affected } & $\begin{array}{l}1 \text { household / } \\
\text { farm yards, } \\
1 \text { grasslands }\end{array}$ & $\begin{array}{l}2 \text { household / } \\
\text { farm yards, } \\
1 \text { grasslands, } \\
1 \text { arable }\end{array}$ & $\begin{array}{l}3 \text { household / } \\
\text { farm yards, } \\
2 \text { grasslands, } \\
1 \text { arable }\end{array}$ & $\begin{array}{l}3 \text { household / } \\
\text { farm yards, } \\
2 \text { grasslands, } \\
3 \text { arable }\end{array}$ \\
\hline \multirow{3}{*}{2} & Only damage & $253 \mathrm{~m}$ & 952 & 631 & 279 & - \\
\hline & $\begin{array}{l}\text { Damage + torrential } \\
\text { rain }\end{array}$ & $490 \mathrm{~m}$ & 1381 & 1958 & 6358 & 7839 \\
\hline & \multicolumn{2}{|c|}{ Landuse category affected } & $\begin{array}{l}1 \text { household / } \\
\text { farm yards, } \\
1 \text { grasslands }\end{array}$ & $\begin{array}{l}2 \text { household / } \\
\text { farm yards, } \\
2 \text { grasslands }\end{array}$ & $\begin{array}{l}5 \text { household / } \\
\text { farm yards, } \\
2 \text { grasslands }\end{array}$ & $\begin{array}{l}11 \text { household / } \\
\text { farm yards, } \\
3 \text { grasslands, } \\
1 \text { orchard }\end{array}$ \\
\hline
\end{tabular}

determine more extensive damage in the case of damage point no. 2 scenario, also because of the higher number of elements at risk.

\section{CONCLUSIONS}

The study of the hydrological risk components in rural areas, risk induced by natural phenomena (torrential rains) or humanly induced (technologic damage to the water supply network) brings elements of novelty to the research.

The applications performed according to the three scenarios emphasize the following:

1. The two hazard categories considered (torrential rain and the damage to the water supply network) generate a total runoff that increases along the flow path. A similar trend is observed also if the torrential rain is the only source of the runoff. The explanation lies in the additional water volume coming from the slopes.

2. If the pipe damage is the only water source of the runoff, the volume decreases along the downstream flow path because of the graduate infiltration.

3. Obviously, the combined action of the two types of hazard has more serious consequences than in the case when they occur separately.

4. The results of the study indicate that in order to create different risk scenarios, every village should be studied individually and that it should have an individual risk management plan for floods of combined factors.

\section{REFERENCES}

Albano, R., Crăciun, I., Mancusi, L., Sole, A. \& Ozunu, A., 2017. Flood damage assessment and uncertainty analysis: the case study of 2006 flood in Ilisua basin in Romania. Carpathian Journal of Earth and Environmental Sciences, 12, 2, 335 - 346

Amaguchi, H., Kawamura, A., Olsson, J. \& Takasaki, T., 2012. Development and testing of a distributed urban storm runoff event model with a vector-based catchment delineation. J. of Hydrology, 420-421, 505-515.

Chendeş, V., 2007. Scurgerea lichidă şi solidă în Subcarpaţii de la curbură. (Liquid and solid runoff in Subcarpathians curvature). $\mathrm{PhD}$ Thesis, Institute of Geography, Romanian Academy, 352 pp.

CORINE Land Cover, 2000. Soil Erosion Risk and Important Land Resources in the Southern Regions of the European Community. An Assessment to Evaluate and Map the Distribution of Land Quality and Soil Erosion Risk. EUR 13233, Luxembourg.

Crăciun, A.I., 2007. Using GIS for establish some parameters useful to measure the time of concentration and runoff coefficient, Geographia Technica, 2, 2, 12-19.

Crăciun, A.I., Haidu, I. \& Bilaşco, Şt., 2007. The SCSCN model assisted by G.I.S.- alternative estimation of the hydric runoff in real time. Geographia Technica, 2, 1, 1-7.

Crăciun, A.I, Haidu, I., Magyari-Sáska, Zs. \& Imbroane, A.I., 2009. Estimation of runoff coefficient according to soil moisture using GIS techniques. Geographia Technica, 4, 2, 1-10.

Environmental and Water Resources Institute (EWRI), 2009. Curve Number Hydrology: State of the 
Practice Editors: Richard H. Hawkins, Timothy J. Ward, Donald E. Woodward, Joseph A. Van Mullem. ASCE, Reston, Virginia, 106 pp.

Florea, N. \& Munteanu, I., 2003. Sistemul român de taxonomie a solurilor (SRTS), Editura Estfalia, București, 183 pp.

Greene, R. \& Cruise, J., 1995. Urban Watershed Modeling Using Geographic Information System. J. Water Resour. Plann. Manage., 121, 4, 318-325.

Gyori, M-M. \& Haidu, I., 2011. Unit Hydrograph Generation for Ungauged Subwatersheds. Case Study: the Monoroştia River, Arad County, Romania. Geographia Technica, 6, 2, 23 - 29.

Gyori, M-M., Haidu, I. \& Humbert, J., 2016. Deriving the floodplain in rural areas for high exceedance probability having limited data source. Environmental Engineering and Management Journal, 15, 8, 1879-1887.

Haidu, I., Batelaan, O., Crăciun, A.I., \& Domniţa, M., 2017. GIS module for the estimation of the hillslope torrential peak flow. Environmental Engineering and Management Journal, 16, 5, 1137-1144.

Haidu, I., \& Ivan, K., 2016-a. Évolution du ruissellement et du volume d'eau ruisselé en surface urbaine. Étude de cas: Bordeaux 1984-2014, France. La Houille Blanche, 5, 51-56.

Haidu, I., \& Ivan, K., 2016-b. The assessment of the impact induced by the increase of impervious areas on surface runoff. Case study the city of ClujNapoca, Romania. Carpathian Journal of Earth and Environmental Sciences, 11, 2, 331-337.

Haidu, I. \& Ivan, K., 2016-c. Ponds delineation in various urban landforms. Case study for Cluj-Napoca, Romania. Environmental Engineering and Management Journal, 15, 6, 1379-1386.

Heggen, R., 2001. Normalized Antecedent Precipitation Index. J. Hydrol. Eng., 6, 5, 377-381.

Istanbullougu, A., Konukcu, F., Kocaman, I. \& Bakanogullari, F., 2006. Effects of Antecedent Precipitation Index on the Rainfall-Runoff Relationship. Bulgarian Journal of Agricultural Science, 12, 35-42.

Ivan, K., 2015. The spatio-temporal analysis of impervious surfaces in Cluj-Napoca, Romania. Geographia Technica, 10, 2, 50-58.

Keller, I.E., Bilaşco, Şt., Haidu, I. \& Văduva, B., 2009a. Using GIS to determine the flooded areas and risk assessment in the water supply system. REV-CAD Journal of Geodesy and Cadastre, 9, 239-248.

Keller, I.E., Bilaşco, Şt. \& Haidu, I., 2009-b. Using GIS to determine the failure risk in the water supply network. The case study of a square from Baia Mare city. Buletinul Institutului Politehnic din Iaşi, Hidrotehnica, LV, 1, 9-18.

Khaleghi, S. \& Mahmoodi, M., 2017. Assessment of flood hazard zonation in a mountainous area based on GIS and analytical hierarchy process. Carpathian Journal of Earth and Environmental Sciences, 12, 1, 311-322.

Kohler, M.A. \& Linsley, R.K., 1949. Recent developments in water supply forecasting from precipitation. Eos, Transactions American Geophysical Union, 30, 3, 427-436.

Luijten, J.C., Jones J.W. \& Knapp E.B., 2002. Spatial Water Budget Model and GIS Hydrological Tools, ICASA (International Consortium For Agricultural Systems Applications).

Marian, R.A., Haidu, I., Crăciun, A.I. \& Văduva, B., 2012. GIS utility for hydrological impact evaluation caused by damages of water supply network in rural areas. Applications in Baia Mare Depression. Geographia Napocensis, VI, 2, 103-109.

Mishra, S., Jain, M.K. \& Singh, V.P., 2004. Evaluation of the SCS-CN-based model incorporating antecedent moisture. Water Resources Management, 18, 6, 567-589.

Mishra, S., Pandey, A. \& Singh, V. - editors, 2012. Special Issue on Soil Conservation Service Curve Number (SCS-CN) Methodology. J. Hydrol. Eng., 17, 11, 1157-1286.

Nicoară, M.E., \& Haidu, I., 2011. Creation of the roads network as a network dataset within a geodatabase. Geographia Technica, 6. 2, 81 - 86.

Sample, D., Heaney, J., Wright, L. \& Koustas, R., 2001. Geographic Information Systems, Decision Support Systems, and Urban Storm-Water Management. J. Water Resour. Plann. Manage. 127, Special issue: mini-symposium on urban drainage, 155-161.

Sample, D. \& Heaney, J., 2006. Integrated Management of Irrigation and Urban Storm-Water Infiltration. J. Water Resour. Plann. Manage., 132, 5, 362-373.

Sandink, D., 2009. Handbook for reducing basement flooding. Institute of Catastrophic Loss Reduction, Toronto, Canada. 57 pp.

Sandink, D., 2011. Involving Homeowners in Urban Flood Risk Reduction. A study case of Sherwood Forest Neighbourhood, London, Ontario. Institute of Catastrophic Loss Reduction, Toronto, Canada, $89 \mathrm{pp}$.

Sarpe, C.A. \& Haidu, I., 2017. Temporal sampling conditions in numerical integration of hydrological systems time series. Geographia Technica, 12, 1, 82-94.

Soil Conservation Service (SCS-USDA), 1986. Urban Hydrology for Small Watersheds. Technical Release, 160 pp.

Taher, S., \& Labadie, J., 1996. Optimal Design of WaterDistribution Networks with GIS. J. Water Resour. Plann. Manage., 122, 4, 301-311.

Tramblay, Y., Bouaicha, R, Brocca, L, Dorigo, W., Bouvier, C., Camici, S. \& Servat, E., 2012. Estimation of Antecedent Wetness Conditions for flood modeling in northern Morocco. HESS Hydrology and Earth System Science, 16, 43754386.

Tudose, T., Croitoru A-E. \& Haidu, I., 2013. Some aspects on rainfall maximum intensity in northwestern Romania. International Multidisciplinary Scientific Geoconference SGEM 2013, Volume I, Section Air Pollution and 
Climate Change, Albena - Bulgaria, 771-778.

Voda, A.I., Sarpe, A.C. \& Voda, M., 2018. Methods of maximum discharge computation in ungauged river basins. review of procedures in Romania. Geographia Technica, 13, 1, 130-137.

Wilkinson, M.E., Quinn P.F. \& Wellton, P., 2008. Belford catchment proactive flood solution: storing and attenuating runoff on farm. BHS $10^{\text {th }}$ National Hydrology Symposium, Exeter, 327-332.

Zaharia, S., Chendeş, V. \& Driga, B., 2011. Flooding occurence within the buit-up areas of Baia Mare. Riscuri şi catastrofe, 10, 1, 175-184.

Zhan, X. \& Huang, M-L., 2004. ArcCN-Runoff: an ArcGIS tool for generating curve number and runoff maps. Environmental Modeling \& Software, 19, 10, 875-879.

Zoppou, C., 2001. Review of urban storm water models. Environmental Modeling \& Software, 16, 3, 195231.

Received at: 16. 09. 2018

Revised at: 02. 11. 2018

Accepted for publication at: 07. 11. 2018

Published online at: 16. 11. 2018 